\title{
Estimation of Evapotranspiration for Onion Crop in Semi-Arid Region: Experimental Field Setup Using Lysimeter
}

\author{
Surendra Halasuru Jayaram*, Darshan Hebballi Thippeswami, Gagan Boraiah Rajashekar, \\ Likith Raj, Shreyas Gowda \\ Department of Civil Engineering, ATRIA Institute of Technology, Bangalore, Karnataka, India
}

\section{Email address:}

surendra@atria.edu (S. H. Jayaram), darshanht65@gmail.com (D. H. Thippeswami), gagancod07@gmail.com (G. B. Rajashekar), likhithrajt@gmail.com (L. Raj), shreyasgowdakj4@gmail.com (S. Gowda)

${ }^{*}$ Corresponding author

\section{To cite this article:}

Surendra Halasuru Jayaram, Darshan Hebballi Thippeswami, Gagan Boraiah Rajashekar, Likith Raj, Shreyas Gowda. Estimation of Evapotranspiration for Onion Crop in Semi-Arid Region: Experimental Field Setup Using Lysimeter. Urban and Regional Planning. Vol. 3, No. 1, 2018, pp. 1-5. doi: 10.11648/j.urp.20180301.11

Received: October 4, 2017; Accepted: December 26, 2017; Published: January 18, 2018

\begin{abstract}
In this work, Blaney-Criddle and Lysimeter method were applied to evaluate the actual evapotranspiration for onion crop in the semi-arid region of Chitradurga district. A reliable and accurate estimation of evapotranspiration are required for proper water balance and to define water-crop requirement. For this purpose, Lysimeter was set up in the field using three different soil layers of specific gravity 2.30. In this research work, an attempt is made to estimate daily evapotranspiration for onion crop, for which $1000 \mathrm{ml}$ of water was added on daily basis and corresponding percolation was observed to find the potential water balance deficit and surplus. Onion is a local crop of Chitradurga district having growth rate 90-120 days. For Blaney-Criddle equation, crop coefficient of 0.75 is adopted to estimate the actual evapotranspiration. This method was found to be simple and reliable to estimate the evapotranspiration in semi-arid region.
\end{abstract}

Keywords: Evapotranspiration, Lysimeter, Onion Crop, Blaney-Criddle Equation

\section{Introduction}

In the context of climatic change, water resources for agriculture are decreasing with respect to time and space in many parts of the world with more emphasis in the semi-arid and arid regions. Demand for water is increasing due to increase in anthropogenic activities, increase in population, rapid industrialization and increase in growing of crops under limited irrigation practices. Hence the necessity of judicious use of water is required for maximum agricultural production. Nearly, $85 \%$ of water is withdrawing from the earth's surface including ground water resource for agricultural activities. Normally in Semi-Arid regions, the scarce of water resources are stored as a ground water; whereas the demand for limited ground water is increasing. For better improvement of water management and to increase water use efficiency of various agricultural production, crop water use should be accurately evaluated.
The process of water released to the atmosphere by different ways includes solids, liquids, soil, and plants surfaces are difficult to distinguish. Hence, together it is termed as evapotranspiration (ET). Evapotranspiration was found to be more sensitive towards climatic variables such as relative humidity, temperature, wind speed, sunshine hours and other parameters. This sensitivity may decrease on different scale index due to variation of climatic variables. Evapotranspiration was found to be more important and integral component of hydrological cycle, which has significant and direct impact on hydrological aspects.

Transpiration is depends on growth rate of plant. The value of evapotranspiration is high in midday and less in morning, hence it is unaffected by air-temperature and humidity. This work presented a simple equation for estimating the actual evapotranspiration $\left(\mathrm{ET}_{\mathrm{a}}\right)$ from climatic and soil parameter using Lysimeter in the semi-arid regions. Consumptive use of water includes water used in plant metabolism and direct 
evapotranspiration from soil and plant surfaces. Thus Consumptive use exceeds Evapotranspiration by the amount of water used for plant metabolism through photosynthesis, transport of minerals, growth of plant and other activities.

Many methods have been applied for the estimation of Evapotranspiration. Some of them are found to be useful for the analysis. The daily values of reference crop evapotranspiration (ETr) were estimated by PenmanMonteith method for 32 years [1]. The study of evaporation and transpiration components of evapotranspiration and to estimate their contributions in semi-arid regions characterized by shallow groundwater table [2]. Analyzing the evaporation and evapotranspiration measured on the caldarusani lake and their influences on the lakes water volume [3]. Numerical simulation of groundwater in this basin (Baoy-ang irrigation area) using FAO PenmanMonteith method under all circumstances [4]. Identifying the factors controlling the variability of Evapotranspiration (including associated atmospheric circulations) [5]. Relation between pan evaporation and actual evapotranspiration by using different types of pan evaporation apparatus [6]. Modified Penman-Monteith method to evaluate the reference evapotranspiration for effective planning and management [7]. Different Evapotranspiration equations were calibrated and used on river Delta region [8]. Approximately $1^{\circ} \mathrm{C}$ increase in temperature could increase ETo by $30 \mathrm{~mm}$ per year [9]. Estimation of reference evapotranspiration (ETo) using the Multivariate Empirical Mode Decomposition [10].

The present method was simple in construction and assessment, for this purpose soil test was done using core cutter apparatus and specific gravity of soil was found to be 2.30. Three different soil layers were prepared in the Lysimeter. Water was added on daily basis with a quantity of $1000 \mathrm{ml}$ and correspondingly percolated value was found to find the potential water balance (surplus or deficit). The Blaney-Criddle equation was used to estimate the actual evapotranspiration and method was found to be reliable for different crop in semi-arid regions.

\section{Study Area}

The present study area covers the Hosadurga located near the fast developing western section of Chitradurga, at $14^{\circ} \mathrm{N}$ to $76.5^{\circ} \mathrm{E}$. The summer season starts from March with temperature ranging from $30^{0}-36^{0}$. At the end of May, the monsoon season starts and lasts until the end of October. The physical features of Chitradurga District are such that, Precipitation is confined to the period between April to October with rainfall ranging from 700 to $900 \mathrm{~mm}$ approximately. During summer the crops are invariably subjected to drought condition. Therefore, it becomes increasingly important to optimize the irrigation needs for the crop in semi-arid regions. Figure 1 shows the location of study area.

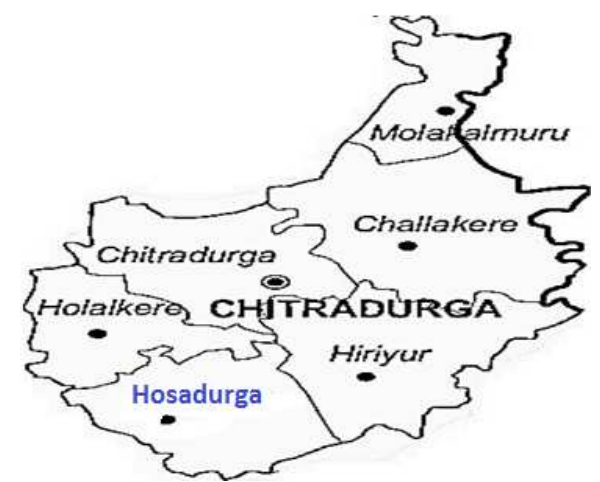

Figure 1. Location of the study area (Hosadurga: Google source).

\section{Methodology}

\subsection{Lysimeter}

Lysimeter is a special type of cylindrical water tight tank which contains soil and was installed in a field with onion crops. The crops grown in lysimeter are same as that of crops in surrounding adjacent crops. Evapotranspiration was measured in terms of the amount of water necessary to maintain adequate and constant moisture conditions. The average value of water required over the crop period in $\mathrm{mm}$ /day will give the value of actual ET in $\mathrm{mm}$ /day under the specified field condition. Lysimeters was designed to accurately replicate the soil conditions, moisture content and type of vegetation around it. It was placed in the soil at the same level of ground. Lysimeter observations are usually combined with rainfall observations.

Figure 2 shows the lysimeter set up in the field. Figure 3 shows the different layers of the soil sample with different size. The figure 4 shows the onion plant in the lysimeter set up.

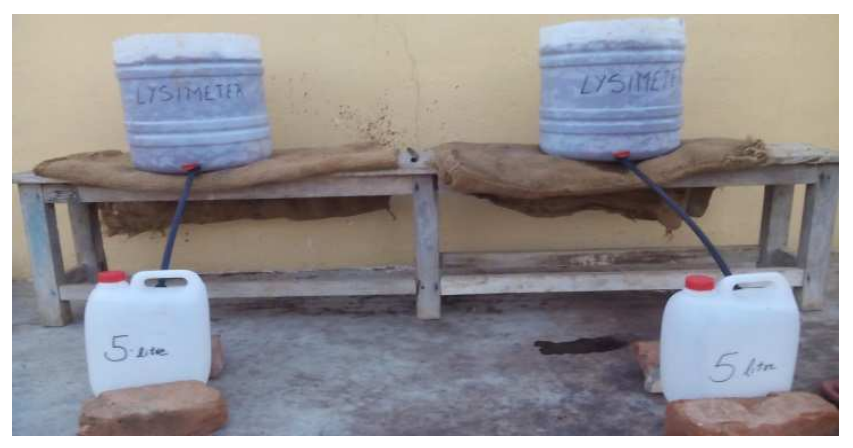

Figure 2. Lysimeter setup in the field.

Evapotranspiration is controlled by the climatic variables and is largely independent of the amount of vegetation present. If the soil and vegetation is confined within a small tank, then the measurements are made using inputs, such as rainfall( $\mathrm{R})$, water added(W) and output (percolated water $\mathrm{P}$ ) collected in the receiver. Henceforth the Evapotranspiration can be estimated from the equation.

$$
\mathrm{PET}=[\mathrm{R}+\mathrm{W}-\mathrm{P}]
$$




\section{$W$-Water added $(\mathrm{ml})$}

$P$-Water percolated $(\mathrm{ml})$

(If PET is positive, it is potential water surplus or else it is potential water deficit).

\subsection{Construction}

1. Tank: The tank was made up of Plastic which is cylindrical in shape and having a diameter of $30 \mathrm{~cm}$ and depth of $30 \mathrm{~cm}$ from surface of soil. A small outlet (opening) is provided near the base to collect the percolated water into a closed container.

2. Installation: Lysimeter was taken to the field, filled with gravel. Local soil which is lateritic is used in the lysimeter up to the desired level, then onion plant was grouted into the soil.

3. Daily procedure: Each day a known quantity of water was added to the crop in the lysimeter. Measurement of the water percolated "P" in mm was taken every day.

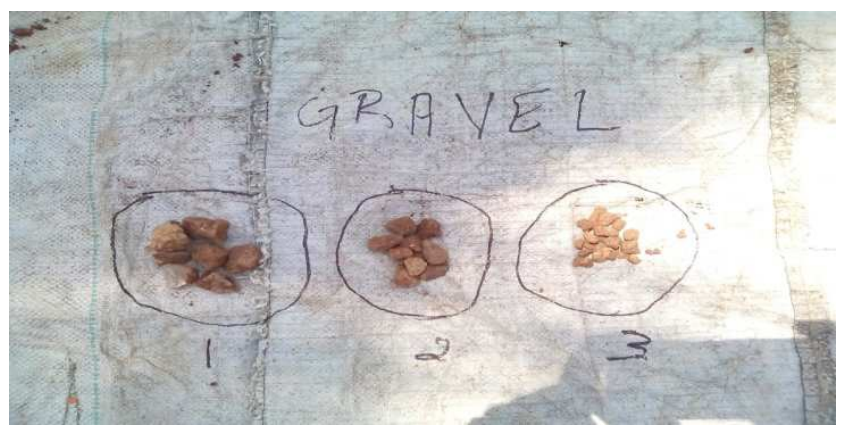

Figure 3. Soil sample used.

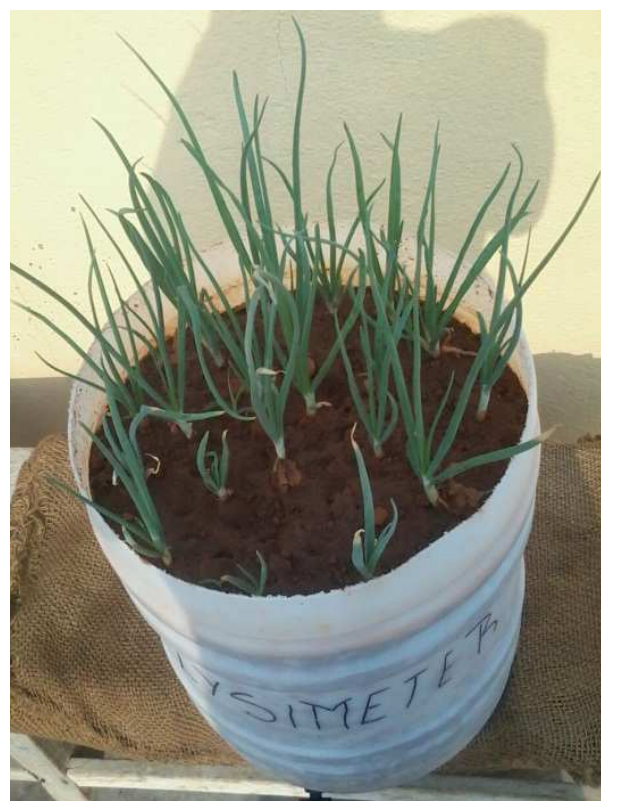

Figure 4. Sample of onion crop.

\subsection{Results}

1. Weight of empty pycnometer (W1) gm $=605$

2. Weight of pycnometer + soil (W2) gm $=900$

3. Weight of pycnometer + soil + Water $(W 3)$ gm $=1680$

4. Weight of pycnometer + Water $(W 4)$ gm $=1513$

\subsubsection{Calculation}

$$
\mathrm{G}=(W 2-W 1) /((W 2-W 1)-(W 3-W 4))
$$

$$
\mathrm{G}=2.3046
$$

\begin{tabular}{|c|c|c|c|c|c|c|c|c|}
\hline Date & $\begin{array}{l}\text { Water added } \\
\text { W }(\mathrm{ml})\end{array}$ & $\begin{array}{l}\text { Percolation P } \\
(\mathrm{ml})\end{array}$ & $\begin{array}{l}\text { Rainfall } \\
(\mathrm{ml})\end{array}$ & $\begin{array}{l}\text { PET } \\
(\mathrm{ml})\end{array}$ & $\begin{array}{l}\text { PET } \\
(\mathrm{mm})\end{array}$ & $\begin{array}{l}\text { Potential water } \\
\text { surplus PWS (mm) }\end{array}$ & $\begin{array}{l}\text { Potential water Deficit } \\
\text { PWD }(\mathrm{mm})\end{array}$ & $\begin{array}{l}\text { Potential Water } \\
\text { Balance PWB }(\mathrm{mm})\end{array}$ \\
\hline $15 / 3 / 2017$ & 1000 & 220 & 0 & 780 & 11.035 & 11.035 & 0 & 11.035 \\
\hline $16 / 3 / 2017$ & 1000 & 260 & 0 & 740 & 10.469 & 10.469 & 0 & 10.469 \\
\hline $17 / 3 / 2017$ & 1000 & 295 & 0 & 705 & 9.974 & 9.974 & 0 & 9.974 \\
\hline $18 / 3 / 2017$ & 1000 & 355 & 0 & 645 & 9.125 & 9.125 & 0 & 9.125 \\
\hline $19 / 3 / 2017$ & 1000 & 410 & 0 & 590 & 8.347 & 8.347 & 0 & 8.347 \\
\hline $20 / 3 / 2017$ & 1000 & 650 & 162 & 512 & 7.243 & 7.243 & 0 & 7.243 \\
\hline $22 / 3 / 2017$ & 1000 & 530 & 0 & 470 & 6.649 & 6.649 & 0 & 6.649 \\
\hline $23 / 3 / 2017$ & 1000 & 520 & 0 & 480 & 6.791 & 6.791 & 0 & 6.791 \\
\hline $24 / 3 / 2017$ & 1000 & 515 & 0 & 485 & 6.861 & 6.861 & 0 & 6.861 \\
\hline $25 / 3 / 2017$ & 1500 & 790 & 0 & 710 & 10.045 & 10.045 & 0 & 10.045 \\
\hline $26 / 3 / 2017$ & 1500 & 826 & 0 & 674 & 9.535 & 9.535 & 0 & 9.535 \\
\hline $27 / 3 / 2017$ & 1500 & 820 & 0 & 620 & 8.771 & 8.771 & 0 & 8.771 \\
\hline $28 / 3 / 2017$ & 1500 & 920 & 0 & 580 & 8.205 & 8.205 & 0 & 8.205 \\
\hline $30 / 3 / 2017$ & 1500 & 970 & 0 & 530 & 7.49 & 7.49 & 0 & 7.49 \\
\hline $31 / 3 / 2017$ & 1500 & 1000 & 0 & 500 & 7.074 & 7.074 & 0 & 7.074 \\
\hline $1 / 4 / 2017$ & 1500 & 1050 & 0 & 450 & 6.366 & 6.366 & 0 & 6.366 \\
\hline $2 / 4 / 2017$ & 1500 & 1040 & 0 & 460 & 6.508 & 6.508 & 0 & 6.508 \\
\hline $3 / 4 / 2017$ & 1500 & 1045 & 0 & 455 & 6.437 & 6.437 & 0 & 6.437 \\
\hline $4 / 4 / 2017$ & 1500 & 1043 & 0 & 457 & 6.465 & 6.465 & 0 & 6.465 \\
\hline $5 / 4 / 2017$ & 2000 & 1220 & 0 & 780 & 11.035 & 11.035 & 0 & 11.035 \\
\hline $6 / 4 / 2017$ & 2000 & 1640 & 356 & 716 & 10.129 & 10.129 & 0 & 10.129 \\
\hline $7 / 4 / 2017$ & 2000 & 1385 & 0 & 618 & 8.701 & 8.701 & 0 & 8.701 \\
\hline $8 / 4 / 2017$ & 2000 & 1400 & 0 & 600 & 8.488 & 8.488 & 0 & 8.488 \\
\hline $9 / 4 / 2017$ & 2000 & 1460 & 0 & 540 & 7.640 & 7.640 & 0 & 7.640 \\
\hline
\end{tabular}

Table 1. Details of water added and percolated. 


\begin{tabular}{|c|c|c|c|c|c|c|c|c|}
\hline Date & $\begin{array}{l}\text { Water added } \\
\text { W }(\mathrm{ml})\end{array}$ & $\begin{array}{l}\text { Percolation P } \\
(\mathrm{ml})\end{array}$ & $\begin{array}{l}\text { Rainfall } \\
(\mathrm{ml})\end{array}$ & $\begin{array}{l}\text { PET } \\
(\mathrm{ml})\end{array}$ & $\begin{array}{l}\text { PET } \\
(\mathrm{mm})\end{array}$ & $\begin{array}{l}\text { Potential water } \\
\text { surplus PWS (mm) }\end{array}$ & $\begin{array}{l}\text { Potential water Deficit } \\
\text { PWD }(\mathrm{mm})\end{array}$ & $\begin{array}{l}\text { Potential Water } \\
\text { Balance PWB }(\mathrm{mm})\end{array}$ \\
\hline $10 / 4 / 2017$ & 2000 & 1495 & 0 & 505 & 7.144 & 7.144 & 0 & 7.144 \\
\hline $11 / 4 / 2017$ & 2000 & 1538 & 0 & 462 & 6.536 & 6.536 & 0 & 6.536 \\
\hline $12 / 4 / 2017$ & 2000 & 1560 & 0 & 440 & 6.225 & 6.225 & 0 & 6.225 \\
\hline $13 / 4 / 2017$ & 2000 & 1555 & 0 & 445 & 6.296 & 6.296 & 0 & 6.296 \\
\hline $14 / 4 / 2017$ & 2000 & 1540 & 0 & 460 & 6.508 & 6.508 & 0 & 6.508 \\
\hline $15 / 4 / 2017$ & 2000 & 1545 & 0 & 455 & 6.437 & 6.437 & 0 & 6.437 \\
\hline
\end{tabular}

Average PET obtained is 7.909.

\subsubsection{Sample Calculation}

Water added $=1000 \mathrm{ml}$

Water percolated $=650 \mathrm{ml}$

$\mathrm{PET}=\mathrm{R}+\mathrm{W}-\mathrm{P}$

$$
=162+1000-650
$$$$
=512 \mathrm{ml}(+ \text { ve Hence PET }=\text { PWS })
$$

\subsubsection{Blanley - Criddle Method}

It was observed that the amount of water consumptively used by crops during their growing seasons was closely corelated with mean monthly temperatures and daylight hours. The relationship developed by Blaney - Criddle in FPS units is stated as follows:

$$
\mathrm{U}=\mathrm{E}_{\mathrm{T}}=[2.54 \times \mathrm{K} \times \mathrm{F}]
$$

Where,

1. $\mathrm{U}=$ Seasonal consumptive use of water by the crop for a given period.

2. $\mathrm{E}_{\mathrm{T}}=\mathrm{PET}$ in a crop season in $\mathrm{cm}$

3. $\mathrm{F}=\Sigma \mathrm{P}_{\mathrm{H}} \mathrm{T}_{\mathrm{f}} / 100$

4. $\mathrm{K}=$ An empirical co-efficient depends on type of crop

5. $\mathrm{T}_{\mathrm{f}}=$ Mean monthly temp in Fahrenheit

6. $\mathrm{P}_{\mathrm{h}}=$ Monthly percent of annual daytime hours.

Consumptive use of water by crop is give by the equation:

$$
\mathrm{U}=\left[\sum \mathrm{kf}\right]
$$

where, $\mathrm{k}=$ Empirical consumptive use crop coefficient

$$
\mathrm{f}=\mathrm{P}(0.46 \mathrm{t}+8.13)\left[\mathrm{t} \text { in }{ }^{\circ} \mathrm{C}\right]
$$

$\mathrm{t}=$ Mean of daily maximum and minimum temperatures in ${ }^{\circ} \mathrm{C}$ over the month considered.

$\mathrm{P}=$ Mean daily percentage of annual day time hours for a given month and latitude.

Table 2. Results of Evapotranspiration estimated using Blanley-Criddle method.

\begin{tabular}{lllll}
\hline Date & $\begin{array}{l}\text { Daily } \\
\text { temperature (t) }\end{array}$ & $\begin{array}{l}\text { Daytime } \\
\text { hours (p) }\end{array}$ & $\mathbf{F}$ & $\begin{array}{l}\text { U=kf } \\
\text { (mm/day) }\end{array}$ \\
\hline $15 / 3 / 2017$ & 26.5 & 12.3 & 249.93 & 6.24 \\
$16 / 3 / 2017$ & 27.85 & 12.3 & 257.57 & 6.43 \\
$17 / 3 / 2017$ & 27.8 & 12.4 & 259.38 & 6.48 \\
$18 / 3 / 2017$ & 27.7 & 12.4 & 264.51 & 6.61 \\
$19 / 3 / 2017$ & 29.5 & 12.5 & 271.25 & 6.78 \\
$20 / 3 / 2017$ & 27.95 & 12.6 & 264.43 & 6.61 \\
$21 / 3 / 2017$ & 28.3 & 12.7 & 268.57 & 6.71 \\
$22 / 3 / 2017$ & 27 & 12.8 & 263.04 & 6.576 \\
$23 / 3 / 2017$ & 26.75 & 12.9 & 263.65 & 6.59 \\
$24 / 3 / 2017$ & 27.2 & 12.1 & 249.76 & 6.24 \\
$25 / 3 / 2017$ & 29 & 12.1 & 259.75 & 6.49 \\
\hline
\end{tabular}

\begin{tabular}{lllll}
\hline Date & $\begin{array}{l}\text { Daily } \\
\text { temperature }(\mathbf{t})\end{array}$ & $\begin{array}{l}\text { Daytime } \\
\text { hours }(\mathbf{p})\end{array}$ & $\mathbf{F}$ & $\begin{array}{l}\text { U=kf } \\
(\mathbf{m m} / \mathbf{d a y})\end{array}$ \\
\hline $26 / 3 / 2017$ & 28.5 & 12.11 & 257.21 & 6.42 \\
$27 / 3 / 2017$ & 28.5 & 12.12 & 257.42 & 6.435 \\
$28 / 3 / 2017$ & 28.5 & 12.12 & 257.42 & 6.435 \\
$29 / 3 / 2017$ & 28.75 & 12.13 & 259.036 & 6.475 \\
$30 / 3 / 2017$ & 28 & 12.14 & 255.06 & 6.3765 \\
$31 / 3 / 2017$ & 30.5 & 12.14 & 269.02 & 6.72 \\
$1 / 4 / 2017$ & 28.25 & 12.15 & 256.66 & 6.41 \\
$2 / 4 / 2017$ & 28.75 & 12.15 & 259.24 & 6.481 \\
$3 / 4 / 2017$ & 29.5 & 12.14 & 263.43 & 6.58 \\
$4 / 4 / 2017$ & 29 & 12.16 & 261.075 & 6.52 \\
$5 / 4 / 2017$ & 30 & 12.19 & 261.719 & 6.54 \\
$6 / 4 / 2017$ & 29 & 12.19 & 261.719 & 6.54 \\
$7 / 4 / 2017$ & 29 & 12.20 & 261.934 & 6.54 \\
$8 / 4 / 2017$ & 28.5 & 12.20 & 259.128 & 6.47 \\
$9 / 4 / 2017$ & 28.45 & 12.21 & 259.06 & 6.47 \\
$10 / 4 / 2017$ & 30.5 & 12.22 & 270.79 & 6.76 \\
$11 / 4 / 2017$ & 30 & 12.23 & 268.20 & 6.705 \\
$12 / 4 / 2017$ & 30.5 & 12.23 & 271.01 & 6.77 \\
$13 / 4 / 2017$ & 29.5 & 12.25 & 265.82 & 6.64 \\
$14 / 4 / 2017$ & 30 & 12.25 & 298.64 & 6.71 \\
$15 / 4 / 2017$ & 31 & 12.25 & 274.27 & 6.85 \\
\hline
\end{tabular}

Average consumptive use of water by Blanley-Criddle method is 6.491 .

$$
\begin{aligned}
& \text { 3.3.4. Sample Calculation } \\
& \mathrm{f}=12.30(0.46 \times 26.5+8.13) \\
& =242.67 \\
& \mathrm{U}=\mathrm{K}^{*} \mathrm{f} \\
& =0.75 \times 246.67 \\
& =185.0025 \mathrm{~mm} / \mathrm{month} \\
& =185.0025 / 31 \\
& =6.24 \mathrm{~mm} / \text { day }
\end{aligned}
$$

\section{Discussions}

From the table 1, it is observed that, the value of potential evapotranspiration obtained on the first day was found to be $11.03 \mathrm{~mm} /$ day and from the table 2, the value of evapotranspiration was found to be $6.24 \mathrm{~mm}$ /day for BlanleyCriddle equation. The difference in values signifies the growth rate of the crop, but the values obtained in the later stages compensate to the value of beginning stages of crop. Henceforth, the average value of 7.90 and 6.49 are considered. Therefore, the average value of 7.90 and 6.49 is considered from table 1 and table 2 .

\section{Conclusions}

The average value of evapotranspiration for onion crop is found to be $7.90 \mathrm{~mm} /$ day from Lysimeter and $6.49 \mathrm{~mm} /$ day 
from Blaney-Criddle equation method. Lysimeter found to be simple in operation. Henceforth, it can be used effectively to estimate the evapotranspiration for different regions and for different crops.

\section{References}

[1] Deodas T. Meshram, S. D. Gorantiwar, N. V. Singh and R. K. Pal (2014), "SARIMA model for generation and forecasting of pomegranate (Punicagranatuml.) Evapotranspiration of Solapur district of Maharashtra, India”. $2^{\text {nd }}$ International conference on Agricultural \& Horticultural Sciences Feb 03052014.

[2] E. Balugani, M. W. Lubczynski, L. Reyes-Acosta, C. van der Tol, A. P. Francis, K. Metseler (2017) "Ground water and unsaturated zone evaporation and transpiration in semi-arid open good land”. Journal of Hydrology 547 (2017) 54-66.

[3] Florentina-iulianastan, GianinaNeculau, LilianaZaharia, Gabriela Ioana-Toroimac, Sorin Mihalache (2016) "Study on evaporation and evapotranspiration measured on Caldarusani Lake (Romania)". Procedia Environmental Sciences 32 (2016) $281-289$.

[4] Hussein. Ahmed, Junmin Liu (2013), “Evaluating Reference Crop Evapotranspiration (ETo) in the Centre of Guanzhong Basin”, Engineering, 2013, 5, 459-468.
[5] Hugo g. Hidalgo, Daniel r. Cayan, Michael d. Dettinger (2015), "Sources of Variability of Evapotranspiration in California", Journal of hydrometeorology Volume 6.

[6] Hongchao Zuo, Bolong Chen, Shixin Wang, Yang Guo, Bin Zuo, Liyang Wu, Xiaoqing Gao (2016) "Observational study on complementary relationship between pan evaporation and evapotranspiration and its variation with pan". Agricultural and Forest Meteorology 222 (2016) 1-9.

[7] Isikwue, C. Bernadette, Audu, O. Moses, Isikwue, O. Martin. (2014), "Evaluation of Evapotranspiration using FAO Penman-Monteith Method in Kano Nigeria". International Journal of Science and Technology, Volume 3 No. 11.

[8] Koffi Djaman, Houssein Tabari, Alpha B. Balde, Lamine Diop, Koichi Futakuchi, Suat Irmak (2016) "Analysis, calibration and validation of evapotranspiration models to predict grass-reference evapotranspiration in the Senegal River delta". Journal of Hydrology: Regional Studies 8 (2016) 82-94.

[9] S. Shekhar (2012), "Study of Evapotranspiration in Context of Changing Climate". Journal of Mechanical and Civil Engineering 2278-1684 Volume 2, Issue 6 (Sep-Oct 2012), PP 13-16.

[10] S. Adarsh. SulaimanSanah, K. K. urshide, P. Nooramol (2017) "Scale dependent prediction of reference evapotranspiration multi-variate empherical mode decomposition". Ain Shams Engineering Journal (2017). 